\title{
Not in the Name of the "Other": The Democratic Concept of International Adjudication through the Looking Glass
}

\author{
Parvathi Menon"
}

\section{Introduction}

International lawyers and institutions today, charged with a cosmopolitan ethos, demonstrate the desire to project a technicality that they hope will bring legitimacy to their projects. Pushing states to the background as mere intermediate stages in the rise of a global federation under the rule of law, they portray international law as the saviour of individual human rights against the marked politics of state sovereignty ${ }^{1}$. The "technisization" of different regimes in international law has enabled the fragmented fields to push against each other's specialization as a means to prioritize their own agendas, leaving open the perennial question: who has jurisdiction? In other words, who can decide? While a clash of jurisdictions playing out the political choice making at the international institutional level has received much attention already, von Bogdandy and Venzke turn the question on its head in their book and ask "In Whose Name" do these institutions decide?

Shifting the focus from the jurisdictional question to the space of representational politics ${ }^{2}$ raises umpteen questions and concerns. In the current international legal sphere of innumerable courts and tribunals, with each

* Researcher, Erik Castren Institute of International Law and Human Rights, University of Helsinki.

1 This theme has been discussed in detail by Koskenniemi, M. (2005), From Apology to Utopia: The Structure of International Legal Argument, Reissue with a New Epilogue. Cambridge: Cambridge University Press, and later mapped in: Koskenniemi, M. (2002), The Gentle Civiliser of Nations. The Rise and Fall of International Law 18701960. Cambridge: Cambridge University Press. See also: Lauterpacht, H. (1933), The Function of Law in the International Community. Oxford: Clarendon Press.

2 While using the term "representational politics", I do not equate representation with democracy, albeit I use the phrase alluding to the space of democratic politics the authors von Bogdandy and Venzke refer to, in which representation can occur. See: Ernesto L. (1996), Emancipation(s). London: Verso. See also: Laclau, E. \& Mouffe, Ch. (2001), Hegemony and Socialist Strategy. London: Verso, where they describe a representation of interests as one where there is a transparent relation- 
institution having their own internal hierarchies and schemas, to speak in the name of the people begs the question who those people are, to avoid projecting a homogeneity on the "represented", and which people get excluded when we make such determinations. Would refugees or sans papier migrants fit within the category of people in whose name international courts speak? Furthermore, this would require an understanding of whose agenda the court is advancing and whether that agenda continues to have a Westphalian bias, primarily. Nonetheless, even within the Westphalian contours, the heterogeneity of the "people" begs the question whether institutions like the International Criminal Court are speaking in the name of the Africans they target, or the Western world they mostly refrain from targeting. Whether the European Court of Human Rights speaks in the name of all Europeans or merely in the name of a Western European ethos they believe will help civilize the Eastern Europeans. At the same time, would transposing a representative element onto these institutions run counter to their depoliticized frameworks? Lastly, the "in whose name" question downplays the importance of the decision maker, because it suggests that no matter which court ends up having jurisdiction, what eventually matters is that they speak in the name of the people.

Resolving these tensions necessitates zooming both in and out. Von Bogdandy and Venzke idealize the "unique possibility of giving a voice to individuals who are affected by the actions of a foreign state", or one's own State. Yet, they remain pragmatic in recognizing the limits of such a possibility, deeming it "indispensable to the legitimation of every court that it operates at a distance from political processes" ${ }^{3}$. Portraying international courts as "beacons of humanity" that place limits on states' exercise of power based on a "universal community of values", they cater to what has become a standard trope among international law scholars: of the international's rescue from state authoritarianism. Treating the international as a means to ameliorate cases of democratic exclusion domestically, such a stance affords international courts the opportunity to set right flagrant violations occurring domestically, whilst ignoring completely whether these courts themselves can perpetuate the exclusion they sometimes prevent. Courts as "actors of international public authority" can be a useful premise, given the competition between functional regimes. ${ }^{4}$ How-

ship between the representative and the represented, wherein the former promotes the interest of the latter.

3 Von Bogdandy, A. and Venzke, I. (2014), In Whose Name?: A Public Law Theory of International Adjudication. Oxford: Oxford University Press, 19.

4 Ibid., 100. 
ever, that would also require an international political society that is capable of determining the jurisdiction and extent of such public authority. Not unlike the inter-war liberal internationalism, the public theory of adjudication rests upon the managerial underpinnings of a global federation idea that was rife during that period. Yet, in the absence of such a federation of global legislative mechanism, it is perhaps a worthy reminder that we are in fact in a world of competing hegemonic ideas, and not the global constitutionalism that such an international public authority is deemed to create. ${ }^{5}$

On the other hand, while zooming in, it seems perturbingly obvious that many of the suppositions of international equality and humanitarianism, which have become the signposts of a liberal idea of legality, rest on the technicalities of procedural guarantees. These guarantees, on a closer inspection, reveal the structural biases that aid greatly in the determinations of fairness or other standards that lend the system its legitimacy. By focusing on whom these guarantees safeguard, problematic as they already are, the theory ignores who chose them as the hallmark of universal standards, and what those choices entail in allowing an enduring legacy of a constitutionalism resembling empires of the $18^{\text {th }}$ and $19^{\text {th }}$ centuries. Questioning whether procedural systematization accounts for the diversity within the international community or its distribution of resources will foster an understanding of the field as one that is full of contestable and contested choices.

In this paper, I focus on two different sides of the relationship between international adjudicatory mechanisms and the democratic inclusiveness they project onto the international: an external and an internal perspectives. In the external perspective, I shall pan out to examine whether the democratic ideal of the international adjudicatory bodies engages with the history of the field, its undemocratic origins, and the contestations that currently reproduce its asymmetrical beginnings. The external allows me to demonstrate how the power structures at play embolden a type of exclusionism and particularity in the name of inclusion and universalism in international courts and tribunals. Thereafter, the internal view will close in on some of the specific guarantees or standards that define democratic legitimacy of courts. Standards such as impartiality and independence of

5 See: De Wet, E. (2006), “The Emergence of International and Regional Value Systems as a Manifestation of the Emerging Constitutional Order", Leiden Journal of International Law 19(3), 611-632. Cf. Koskenniemi, M. (2007), "International Law: Constitutionalism, Managerialism and the Ethos of Legal Education”, European Journal of Legal Studies (1), 1-18. 
judges or, more generally, a procedural fairness, I argue, discount the actuality of the issues plaguing the international system. Whether procedural fairness can ensure substantive fairness in these international courts and tribunals that were built on uneven playing fields will form the second part of my analysis. In gauging the (internal) relationship between international courts and people, this paper shall examine the substantive and procedural mechanisms stated to enable such representation; whether concepts such as fairness, in relation to judges (i.e., impartiality) along with its procedural guarantees, expose international law's conflicting reality will form the basis of the examination. In other words, this paper will study the implications of the democratic ideology that has long pervaded international law by relying on examples of its perpetuation of the NorthSouth "dynamic of difference" 6 .

\section{Europe vis-à-vis the Rest: Democracy and Its Discontents in International Adjudication}

When the effort towards democratization was made in relation to states, it brought about a wave of ambition, implicitly forcing states to re-model and restructure in order to meet the prescribed standard to be worthy of membership into the international community. ${ }^{7}$ Democracy was becoming the basis for governmental legitimacy in international law, evidenced by the work of Thomas Franck. ${ }^{8}$ Political theorists like Hanna Pitkin treaded more cautiously because of the various meanings she ascribed to democratic representation-delegation, trusteeship, descriptive and symbolic representation-arguing that representation does not mean democracy (and most often runs counter to any real democracy). ${ }^{9}$ Scholars like von Bogdandy and Venzke, but also others like Richard Bellamy who engage with the question "who represents whom and how" allow representation to pivot on the existence of formal democratic processes of authorization and accountability to ensure democratic values are being pro-

6 Anghie, A. (2005), Imperialism, Sovereignty, and the Making of International Law. Oxford: Oxford University Press.

7 Franck, T. (1992), "The Emerging Right to Democratic Governance”, American Journal of International Law 86(1), 46-91.

8 Marks, S. (2011), "What has become of the Emerging Right to Democratic Governance?", European Journal of International Law 22(2), 507-524.

9 Pitkin, H. (1967), The Concept of Representation. Berkeley: University of California Press. 
moted. ${ }^{10}$ Although von Bogdandy and Venzke explicitly refrain from attributing any real representational quality to judicial institutions, they allude to the election of judges as an example of what representation can entail in such bodies. ${ }^{11}$

The marriage between democracy and legitimacy became the clarion call for the international community to recalibrate its expectations towards states seeking membership into its hallowed institutional circles. If we look at the debate that arose after Thomas Franck published his influential piece on democracy, there was a clear shift from the community to the individual: the kind of serious individualism that mirrored the universality it celebrated. ${ }^{12}$ Equally, there was also an emerging cosmopolitanism that celebrated the "context-dependent variety of legitimate actions, of lawyers and courts, not through judicial technique, but rather through the intuitive application of good sense"13. This good sense, it was imagined, united people like the logic of the market. Democracy implied such good sense, or vice versa.

While democracy has been prescribed as the preferred process to bridge the legitimacy gap in international courts and institutions, scholars opine, "an institution is legitimate if its power is justified in terms of moral and other socially embedded beliefs, and if those subject to its rule recognize that it should be obeyed" 14 . If we presume the democratic process to be one of such belief, there is no doubt that its fulfilment would grant international courts its requisite legitimation. Yet, this presumption overlooks two aspects: firstly, is democracy as desirable as its endorsement reflects? Secondly, if yes, is international law itself a product of such a democratic process that can grant legitimacy according to the thesis put forward by the authors?

10 Bellamy, R. and Castiglione, D. (2011), "Democracy by Delegation? Who Represents Whom and How in European Governance", Government and Opposition 46(1), 101-125.

11 Von Bogdandy and Venzke, supra note 3, 148.

12 Koskenniemi, M. (2002-2003), "Legal Cosmopolitanism: Tom Franck’s Messianic World", NYU Journal of International Law and Politics 35, 471-486, 481. Von Bogdandy and Venzke refer to the Treaty of the European Union as embodying such individualistic approaches, tracing it back to a Kantian or Hobbesian idea. Von Bogdandy and Venzke, supra note 3, 140.

13 Ibid.

14 Zaum, D. (2013), "International Organizations, Legitimacy and Legitimation" In: D. Zaum (ed.), Legitimating International Organizations. Oxford: Oxford University Press, 3-25, 9. 
From the liberal democratic theory to deliberative democracy and other discursive approaches, the history of the democratic tradition has seen a variety of descriptions. Even if the history has not been without turbulence, ${ }^{15}$ scholars - both Western and otherwise-have praised the universal appeal and value of democracy. ${ }^{16}$ Its practice, however, has degenerated from a concept of direct citizen participation to one that has become only indirectly plausible. Citizen participation in the decision-making process, as one of the ideals of democracy, has been hardly met by modern states. ${ }^{17}$ In fact, the concept of democratic decision-making has been reduced to the individuals' right to vote, evincing the disappearance of "the more radical association of democracy with popular power" in Western thought. ${ }^{18}$ Despite the dissonance, the dissonance, international law has implicated notions of democracy.

The evolution of democracy within the context of international law has met with strong opposition with regard to its credentials, historically, as being a "product of the interests and practices of imperial powers"19. International law and its initiative to bring about "good governance" began (re)colonizing through the language of globalization. "The concept of good governance, in turn, generated more specific programs focusing on how international law and institutions could promote democratic governance and legitimate governance." ${ }^{20}$ Antony Anghie focuses on institutions that have higher impact on the peoples of the Third World, like the IMF and the World Bank, in order to demonstrate how "despite the opportunities and advantages it is supposed to create, [it] has intensified inequalities between the West and the Third World" through the use of the concept of governance. Much like the mantra of global governance, myriad legal prin-

15 Charlesworth, H. (2014), "Democracy and International Law", Collected Courses of the Hague Academy of International Law 371, 54-69. For example, the fall of the Berlin Wall in 1989 was thought to be the turning point, a "possible end point in mankind's ideological evolution and the universalization of Western liberal democracy as the final form of human government" (Fukuyama, F. (1992), The End of History and the Last Man. New York: Free Press, 4).

16 See: Sen, A. (1999), "Democracy as a Universal value", Journal of Democracy 10(3), 3-17. See also: Ibrahim, A. (2006), "Universal Values and Muslim Democracy", Journal of Democracy 17(3), 5-12.

17 Dahl, R. (1956), A Preface to Democratic Theory. Chicago: Chicago University Press. See also: Dahl, R. (1989), Democracy and Its Critics. New Haven: Yale University Press.

18 Charlesworth, supra note $15,60$.

19 Ibid., 70-95.

20 Anghie, supra note 6, 246. 
ciples in international law bear the burden of European thought and history. Tracing the genealogies of any of them would lead us to seeing the shaping of the world from a very Eurocentric point of view.

The public theory of adjudication comes with its own guilt of presuming how the European solution could be fitted and adjusted to other jurisdictions. Whether it may be possible or not does not form the basis of my argument, but the presumption that it is an ideal worth pursuing based entirely on the European experience calls for criticism, similar to those levied by scholars against the European origins of international law. ${ }^{21}$ The liberal theory of democracy, despite its undemocratic creation, has brought about a formulaic approach to the requirements that must be met in order to increase the prospects for peace under international law. ${ }^{22}$ Anne-Marie Slaughter argues that international law makes no difference between liberal and non-liberal states under the law; yet, there is an inherent perception that the liberal state is the Gold Standard. If we adopt the same stance in the case of the democratic theory of adjudication, we find that the criteria listed out as the measures to meet in order to fulfil the liberal ambition carries forward the implicit desire to impose the European expectation onto non-Western experiences.

When it came to international organizations, the model of democracy was considered as aspirational as it was in the case of states. Albeit, as explicated by Robert Dahl in his chapter on democratic functioning of international organizations, popular control in democratic countries was admittedly difficult, making the case of international organizations (or courts, in this case) an aggravated problem. ${ }^{23}$ Relying on the difficulties that arise from the epistemic limits, cultural diversity and procedural factors, Dahl portrays the farfetchedness of any type of control that a people can exert on decision-making in international organizations. With respect to the procedural factors, specifically, he maintains that the substantive and pro-

21 See: Ibid.; Koskenniemi, M. (2001), Gentle Civilizer of Nations: The Rise and Fall of International Law, 1870-1960. Cambridge: Cambridge University Press.

22 Marks, S. (2000), The Riddle of all Constitutions: International Law, Democracy, and the Critique of Ideology. Oxford: Oxford University Press, 43; Cf. Slaughter, A.-M. (1992), "Towards an Age of Liberal Nations", Harvard International Law Journal 33(2), 393-495, 403.

23 Dahl, R. (1999), “Can International Organizations be Democratic? A Skeptic's View" In: I. Shapiro and C. Hacker-Cordoj (eds), Democracy's Edges. Cambridge: Cambridge University Press. 
cedural hurdles to realize "public good", as in the case of governments, become more pronounced when exported into the international sphere. ${ }^{24}$

Von Bogdandy and Venzke use the Treaty of the European Union (TEU) as a point of reference to elucidate the concept of democracy for institutions beyond the state. ${ }^{25}$ They consider citizenship (Article 9), representation (Article 10), deliberation, participation, transparency, responsiveness and control (Article 11) and a reorientation of domestic parliamentarianism (Article 12) as the pillars of democratic engagement. Transposing these values from the TEU onto the international judicial framework presumes the efficiency of the values in delivering the "democratic" end product within the context of the European Union, even if clearly stated that it does not offer an exemplar of ideal democratic governance. The TEU, considered the result of democratic politics via the Lisbon Treaty, it is said, carries the legitimacy that comes with such a long process of deliberative and elaborate procedures. However, requiring democratization to legitimize governance or (public) authority in its move from the local to the universal has standardized the democratic expectation, and therefore reduced its engagement with ground realities. Reducing the differences, whilst normalizing the (democratic) expectation, creates an illusion of homogeneity, even in the European context, let alone beyond the European borders. Thus creating a concept of "international democracy" leaves much to be desired. ${ }^{26}$

Von Bogdandy and Venzke, while claiming that "political representation is indispensable", are also clear that "it does not exhaust the democratic idea". Relying on the Treaty of the European Union, they believe that "Article II of the TEU contains further guidelines for more inclusiveness. Transparency, the involvement of affected individuals, and dialogue-the cornerstones of Article II-are of particular importance for an international judiciary, because they identify strategies by which courts can contribute to their democratic legitimation" 27.

Equating participating in the "political process" to emancipation or political inclusion is one of the well-known critiques against democracy. I can see how a politically emancipated population/citizens, through very localized institutional mechanisms for example, can probably feel a part of

24 Benhabib, S. (2014), "Democratic Sovereignty and Transnational Law: On Legal Utopianism and Democratic Skepticism”, APSA 2014 Annual Meeting Paper, 1-52, available at https://ssrn.com/abstract=2455436, accessed 7 February 2020.

25 Von Bogdandy and Venzke, supra note 3, 136.

26 Ibid., 139.

27 Ibid., 152. 
a vertically upward legitimation process, but it is unclear how positive law from above can emancipate the disenfranchised groups at the bottom, using techniques that involve reinforcements of rights they barely possess. This begs the question: how does one relate binding every public authority by these human rights to the "bureaucratic vocabulary human rights have become, available for defending whatever interests or preferences the speaker wants to defend" 28 . A right is one thing, but the expediency of the right could be quite another.

\section{A. Democratic Inclusion and Exclusion}

The conundrum surrounding the failure of the democratic objective in adjudicatory bodies leaves us with the oft-asked question: what are the other alternatives? In the engagement between courts and the people approaching its corridors, as I argued above, the depoliticization of law has been the primary reason for the court's inability to go beyond the sophistry of the law. What once used to be achievable through political recourse today is inhibited by a technicization of the means to achieve it. Yet, the persisting problem with the liberal idea of legality is exactly that: the projection of a neutral formula that does not submit itself to the vagaries of politicking. The public theory of international adjudication falls prey to such excessive legalization, within the realm of international law, when it espouses that positive law can form the basis of a democratic concept of the judiciary's workings. In this section, I will rely on the jurisprudence of two courts: one, which von Bogdandy and Venzke credit with a high degree of "democratic legitimation": the European Court of Human Rights (ECHR), and two, which the scholars admit lacks sufficient democratic quotient: the International Criminal Court (ICC). I argue that while both these courts work differently and pursue different agendas, they both project an inclusive and exclusive ideal, contesting the characterization of their varied levels of democratic legitimacy. Such an approach helps establish two aspects: one, that the democratic quotient of the human rights language as protecting communities from domestic exclusion is flawed, much like that of the ICC, which has received its fair share of criti-

28 Koskenniemi, M. (2006), "Human Rights Mainstreaming as a Strategy for Institutional Power", Humanity: An International Journal of Human Rights, Humanitarianism, and Development 1(1), 47-58, available at https://muse.jhu.edu/article/394857/ pdf, accessed 7 February 2020. 
cism for its selection of cases. Two, even if the democratic legitimacy rests upon a procedural approach of representativeness, the substantive asymmetries project the ethnocentrism procedural guarantees try to avoid.

The ECtHR employs what von Bogdandy and Venzke call the "community-based approach", reflecting the "European consensus". The "thick layer of legal normativity over domestic constitutions" that the ECtHR lays down is understood as stabilizing the normative expectations. ${ }^{29}$ Created to address complaints by individuals against their State, the ECtHR demonstrates an equality that brings out through its inclusiveness a type of rational cosmopolitanism that goes beyond kind of "self-other" distinction endemic to international law more generally. ${ }^{30}$ Such cosmopolitanism may even become convincing to the detractors of universalism to be a reality they must accept. Yet, what we see in the jurisprudence coming from the court is a range of diverse notions of how discrimination looks, for example.

In a set of cases, where the court dealt with the meaning and import of Article 14, it has prevented discriminatory acts based on the individuals' identities as Roma, Jewish, Turkish origins etc. The court has also maintained that the right to practice one's own religion and manifest it is unconditional and absolute under Article $9 .{ }^{31}$ Equally, the same court issued a series of decisions allowing Turkey, France, and Belgium to ban headscarves or veils, as not being in violation of Article 9. Starting with Leyla Şahin v. Turkey (2004), the court persistently upheld that the banning of scarves did not violate the European Convention on Human Rights (Convention). Following the Turkish case, the ECtHR went on to uphold its decision in S. A. S v. France (2014) and in the twin cases of Dakir v. Belgium and Belcacemi and Oussar v. Belgium (2017). Describing the veil ban cases as those where the court took into account the domestic contexts, it was held that "the choice of the extent and form such regulations should take must inevitably be left, up to a point, to the State concerned". The cosmopolitanism of the court and its European consensus thus reverted to the

29 Von Bogdandy and Venzke, supra note 3, 70.

30 The Third World Approach to International Law (TWAIL) highlights the distinction to enumerate how international law continues to uphold the civilizational discourse between the Global North and the South, using it as a mechanism to exercise control whilst projecting a type of faux sovereign equality. See: Anghie, supra note 6. See also: Said, E. (2014) [1979], Orientalism. London: Penguin.

31 Ivanova v. Bulgaria, ECtHR Application No. 52435/99, Judgement of 12 April 2007, para 79; Mockute v. Lithuania, ECtHR Application no. 66490/09, Judgement of 27 February 2018, para 119. 
State, after all, in the name of maintaining public order. The ECtHR sacrificed its community-oriented approach at the altar of security concerns of a state-oriented world. Such conflicting rights are at the very core of human rights adjudication, thus making any cosmopolitan aspiration merely a cover under which the status quo remains. If the community-oriented approach constantly clashes with its state-oriented surroundings, confronting its own limits, the possibilities of the 'international' pushing the States to provide for a domestic inclusive community fails before it even begins. At the same time, requiring international adjudicative bodies to foster inclusion in domestic societies equally presupposes a clarity surrounding what individual identity means and its treatment in the most unidimensional manner. Thus, in the words of Koskenniemi, the liberal idea of legality continues in the pragmatic space of the in-between: a little more than positive law and a little less than morality. ${ }^{32}$

The pragmatism accompanying what we today herald as democratically legitimate spaces of international adjudication becomes more precarious in fields such as international criminal law. Openly admitting to its struggle between individual criminal responsibility and its need for State cooperation to prosecute international crimes, the international criminal court in all its cosmopolitan fervour deems its agenda as rising above all differences, given the ius cogens nature of the crimes it wishes to prosecute. Fighting impunity implies that all victims and the "interests of justice" remain paramount to the court, until it faces its own boundaries when it wants to investigate the crimes committed by the US armed forces in Afghanistan. Determining that such an investigation would not be in the "interests of justice", the Pre-Trial Chamber enunciates "interests of justice" from an extremely pragmatic point of view. In the words of the presiding judge, Justice Mindua, "an investigation can hardly be said to be in the interests of justice if the relevant circumstances are such as to make such investigation not feasible and inevitably doomed to failure"33. Any kind of radicalism that may have been attributed to the court finally investigating the hegemon turned into a case of the Emperor merely wearing new clothes, even if it was not the only basis of the court's decision. Nonetheless, the clash between a variety of cosmopolitanism ushered in by the international criminal court and its pragmatic view of justice as something to be pur-

32 Koskenniemi, M. (1997), "Lauterpacht: The Victorian Tradition in International Law”, European Journal of International Law 8(2), 215-263.

33 Decision Pursuant to Article 15 of the Rome Statute on the Authorisation of an Investigation into the Situation in the Islamic Republic of Afghanistan, ICC Pre-Trial Chamber II, 12 April 2019, para 90. 
sued only if "feasible" is a glaring reminder of the limits of international adjudication and a welcome step towards its acceptance. At the same time, the court in a prior case of Prosecutor v. Jean Pierre Gombo Bemba ${ }^{34}$ chose the technicalities of the law ("rule of law") 35 in favour of what some scholars called the "interests of the victims" 36 . A case of competing universalisms, scholars on both sides of the debate argued whether procedural justice or substantive justice satiated their appetite for inclusiveness. Choosing the former means that the excessive technisization shrouds the real purpose of the court: to fight impunity. The latter implies a disservice to the processes the court must uphold: fair trials and equality of arms. ${ }^{37}$ Beyond the struggle of the ICC between these competing interests, the question that has loomed large over the court has been whether in the quest for procedural fairness while fighting impunity, the court's "radar for racism is permanently broken" 38 .

What I describe as substantive justice, which demands that victims feel vindicated, does not take away from the larger asymmetries that plague the court, or courts more generally. Whether it is the exclusion of the Muslim "other" or the African "other", the courts do not shy away from imposing in the name of procedural guarantees and rule of law what is an inherent Eurocentrism upon the rest of the world. Who that includes and who that excludes may not be immediately discernible in courts other than the ICC, but a closer look into their workings reveal that no court, not even the one with the highest democratic quotient, is free from its European bias.

34 Case No ICC-01/05-01/08-3636-Red (Official Case No) ICL 1849 (ICC 2018).

35 Heinze, A. (2018), "Some Reflections on the Bemba Appeals Chamber Judgment", Opinio Juris, 18 June, available at http://opiniojuris.org/2018/06/18/some-reflectio ns-on-the-bemba-appeals-chamber-judgment/, accessed 7 February 2020.

36 See: Sadat, L. (2018), "Fiddling While Rome Burns? The Appeals Chamber's Curious Decision in Prosecutor v. Jean-Pierre Bemba Gombo", EJIL: Talk!, 12 June, available at https:/www.ejiltalk.org/fiddling-while-rome-burns-the-appeals-chamb ers-curious-decision-in-prosecutor-v-jean-pierre-bemba-gombo/, accessed 7 February 2020; Amman, D.M. (2018), "In Bemba and Beyond, Crimes Adjudged to Commit Themselves”, EJIL: Talk!, 13 June, available at https:/www.ejiltalk.org/i n-bemba-and-beyond-crimes-adjudged-to-commit-themselves/, accessed 7 February 2020.

37 See: Koskenniemi, M. (2002), "Between Impunity and Show Trials", Max Planck Yearbook of United Nations Law 6(1), 1-35.

38 I thank Sundhya Pahuja for this phrasing. 


\section{B. Who is the Fairest of Them All? The Legitimating Force of Impartiality and Independence}

The book written by von Bogdandy and Venzke presents a very bold thesis of, inter alia, re-imagining the premise of international adjudication through the lens of a democratic process through their public law theory of adjudication. Looking at international courts as more than mere dispute settlers, the book suggests a renewed understanding of judiciaries at the international level. They argue a popular sovereignty thesis: that courts draw their legitimacy not just from the consent of the states, the international community, the parties to the dispute or the regimes they are a part of, but from the people and the citizens they were (indirectly) constituted by. When investigating into the conceptual frameworks within which such a democratic theory functions, it is prudent to begin at the level of its aspirations. Etymologically concerned with the role of people in governance, democracy aspires to consult these people and enable their participation in the process of making choices. ${ }^{39}$ What this consultation entails and how limited these choices may be, are aspects that throw light on the relationship between international courts and the "people". Thereby linking political transformations with socio-economic justice, it is my argument that examining democratic principles against the (in)ability of judicial authorities to ensure such justice exposes the pitfalls of the democratic veil that attempts to equalize even in the face of inherent inequalities. In a Hegelian sense, international institutions created through democratic processes do not bridge the gap between private and communal interest; on the other hand, they decrease the scope for mutual recognition. ${ }^{40}$

The legalisation of the international order and its subsequent bureaucratization become aspects such legitimacy claims miss, and ardently support. The judicial processes and procedures, if anything, relegate political participation to the margins. In doing so, a thesis that lays as its foundation the democratic legitimacy of international adjudication must ironically bemoan the call to politicize. The contradiction that emanates from such a characterization, I argue, is precisely why the idealism related to adjudication's democratic quotient deserves questioning. Two aspects bear import here. First, why does depoliticization remain at the core of judicialization?

39 Franck, T. (1995), Fairness in International Law and Institutions. Oxford: Oxford University Press, 83.

40 Ferro, B. (2019), "Hegel, Liberalism, and the Pitfalls of Representative Democracy”, Hegel Bulletin 40(2), 215-236. 
Depoliticization renders the democratic concept wanting, and forces us to revisit the implications of foisting its idealism upon international courts and tribunals. Second, the legalization of the international order in turn maintains the "dynamic of difference" between the Global North and the South, rendering in its democratic quotient what Susan Marks calls the dominant ideology, subsumed in the judicial processes.

Furthermore, it is important to remember that nation-states create international adjudicatory bodies, whether as part of or separate from an international organizational structure. These international or supranational bodies are further removed from political mobilization than nation-states. At the same time, we should exercise caution with regard to such an approach. Supranational or international institutions are, equally, an extension of the nation-states that constitute them. Relying largely on procedural mechanisms to entrench the so-called democratic quotient into the adjudicatory model perhaps alludes to the illusion that irrespective of the differences between states and people, procedural safeguards are an equalizer, and desirably so. This supposition is inherently problematic for two reasons. One, the procedural guarantees to ensure reasonableness, impartiality, equality etc., presume clarity of the standards, and how they must be met; two, even if the standards are admitted as variable, the procedural fairness - through transparency and a democratic functioning-in its imperviousness to the particularity and variability of the people it applies to, tends to defeats its very purpose. The age of human rights and individualization of the rights language has preferred to ignore the differences, in the attempt to achieve equality. The resolution of this dilemma by means of a distinction between form and content, substance and procedure saw the regulation of the interaction of individuals through the domain of formal and procedural rules, devoid of any content or particularity; blind to particularities such as religion and race. ${ }^{41}$

The Treaty of the European Union, upon which the authors base their procedural mechanisms, opts for an individualistic approach, enshrining fundamental civil and political rights as individual rights. "All citizens shall receive equal attention from its institutions, bodies, offices and agencies." - notwithstanding the paternalistic tone, this provision is said to enshrine the principles of civil equality as the guiding democratic princi-

41 Seth, S. (2012), "The Limits of International Relations Theory: A Postcolonial Critique”, E-International Relations, 24 August, available at https:/www.e-ir.info/2012/ 08/24/the-limits-of-international-relations-theory-a-postcolonial-critique/, accessed 7 February 2020. 
ple. "Rights are a key element in the universalization projects of ideological intelligentsias of all stripes. A universalization project takes an interpretation of the interests of some group, less than the whole polity, and argues that it corresponds to the interests or to the ideals of the whole. Rights arguments do this: they restate the interests of the group as characteristics of all people." 42 The individualization of the rights paradigm has systematically undone the concept of a collective, in its attempt to equalize everyone, beyond their differences. Much like the concept of sovereign equality as enshrined in the United Nations Charter, the universal human rights project does a disservice to the diverse needs of people, either as a collective or as an individual.

Article 9 reinforces, according to the authors, the conceptions of democracy for the international level without positing or requesting the formation of a new people or a new nation, but by relying on the idea of a cosmopolitan or transnational citizenship. Authors believe that this doctrine of a transnational or cosmopolitan citizenship might be relevant to courts based on individual rights, like the European Court of Human Rights, the Inter American Court of Human Rights, and even the International Court of Justice. The basis for this citizenship was individual rights that flowed from supranational sources that can be enforced against domestic and supranational acts that impinged upon them. In Western liberal democracies, public authority requires legitimation through one principal source: the citizens of the polity. The deepest, most clearly engraved hallmark of citizenship in these democracies is that power vests in citizens, to enable institutions that will exercise governance on behalf of, and for, the citizens. However, citizens/individuals are subjects only in the effect of the law, and the ability to go to court and enjoy a right does not emancipate them. "Citizenship should reflect not merely the politics of public authority, but also the social reality of peoplehood and the identity of the polity" ${ }^{33}$; the theoretical framework within which the international public authority speaks in the name of its democratic subject does not reflect that reality.

One of the touchstones of the positive law upon which von Bogdandy and Venzke base their thesis, is that of the courts creating or reflecting popular will, more specifically the "international representativeness" of the

42 Kennedy, D. (2002), "The Critique of Rights in Critical Legal Studies" In: W. Brown and J. Halley (eds), Left Legalism/Left Critique. Durham: Duke University Press, 178-227.

43 Weiler, J.H. (1998), “To Be a European Citizen: Eros and Civilization”, Working Paper Series in European Studies (spring), 1-52, available at https://core.ac.uk/downl oad/pdf/148847645.pdf, accessed 7 February 2020. 
bench-a concept whereby the authors claim the judges can fulfil the democratic mandate entrusted to them, if they render their decisions independently, impartially and expertly. Relying on these high-values in the international sphere, whilst not enunciating an ethnocentrism, is much like Thomas Franck's resort to a procedural gateway to universal values. ${ }^{44}$ Franck describes fairness as a "human, subjective, contingent quality which merely captures in one word a process of discourse, reasoning, and negotiation leading, if successful, to an agreed formula located at a conceptual intersection between various plausible formulas for allocation" 45 .

The concept of legitimation serves particular interest in this context. Considered as the process by which authority is seen as "valid and appropriate", the dark side of legitimation is often obscured by the affirmation it provides. ${ }^{46}$ Max Weber observed that power and legitimation, often derived from the consent of those subjected to it, depends either on the tradition, on the personal traits of the leader, or the legality of the rules laid down. ${ }^{47}$ That this leads to the most "legitimate" means to dominate often goes unheeded. International courts, like any other institution, wield power that determines how precedents are created and how the normative world is shaped. Their deriving legitimacy through a means that may be democratic does not necessarily avoid the relations of domination they are able to maintain, by virtue of the functional importance they possess. The halo over democratic functioning, as asserted by liberal theorists, is often misguided to the point of heralding representativeness, impartiality and independence of the judiciary as the hallmarks of its success. The theory of democratic adjudication of international courts, by putting forth such a viewpoint, normalizes such expectation and equalizes the (diverse) people it claims to represent. The lack of popular will is imaginably apparent, although the existing procedure, process and the rule of law that are present are all components of the Liberal theory of democracy. ${ }^{48}$

44 See: Tasioulas, J. (2002), "International law and the Limits of Fairness", European Journal of International Law 13(4), 993-1023. In this article, the author compares Franck's approach to that of the Italian philosopher, Danilo Zolo, in how they tackle ethnocentrism and universal values. While Zolo injects into any type of a universal an inherent ethnocentrism, Franck deflects the criticism by resorting to a procedural mechanism.

45 Franck, supra note 39, 14.

46 Marks, supra note 22, 20.

47 Weber, M. (1965), Politics as a Vocation. Philadelphia: Fortress Press.

48 Kennedy, D. (1997), Critique of Adjudication. Cambridge: Harvard University Press. 
The idea that the judges, through their "democratic" selection, impartiality and independence, can bring about the representativeness within the workings of their court, devoid of any partiality, is perhaps an idealistic supposition. Whilst perceptions of partiality are subjective, the conception of impartiality mandates an objectively plausible view of the law and its application. ${ }^{49}$ I think of judges as part of the political system/State they come from, not just as "appliers" of law made by someone else, but also as formers of the sentiments that express themselves in their decisions, and in treaties or other legal instruments. Without underestimating the judicial contribution to gradual formation of consensus in favour/against something, it still might be simplistic to denounce this process as "undemocratic". There is no "private" sphere in which the will of the people could form without contamination by all the various sources of authority in society. It is equally simplistic to sanitize this authority through the theory that judges reflect changing social ideas and customs. They do indeed reflect them, but in their diversity and above all in their contradictions. ${ }^{50}$ This is not to say that the court does not shape or reshape the demos, but that the judges these days think of themselves as social entrepreneurs or constitutional activists is perhaps indicative of the shift from their previous role of laying foundations of judicial review, a model of rule of law and of adjudication, and guiding of colonial lawyering into a constitutional profession. In their previous role, they were mindful of the wider question of social legitimation of the founding instrument, be it of their court or the demos. Equally, it is important to take note of the dilemma of the judges who, through their election/selection domestically, oscillate between the paradox of increasing the representativeness of the bench because of the state they come from and the decreasing standard of impartiality if they were found not to distance themselves from that state. The basis for this conundrum stems from the hypothesis that the bench can be reconstructed through a democracy-oriented approach.

The fairness of judicial proceedings or the bench evades the incoherence and instability of the meaning of fairness, again. Whom do the judges owe fairness to in the case of an international criminal trial, for example, as the one I outlined above? One of the basic tenets of international criminal law is the right to a fair trial. As Rigney writes, "there appears to be a dedica-

49 Megret, F. (2015), "In Search of International Impartiality”, ESIL Reflections 4(8), 1-6, available at https:/esil-sedi.eu/wp-content/uploads/2015/10/ESIL-Reflection-F rederic-Megret_0.pdf, accessed 7 February 2020.

50 Kennedy, supra note 48, 40. 
tion to fairness amongst international legal practitioners", that it is considered a legitimating force. ${ }^{51}$ Yet, positing how much of the trial must aspire for fairness, Judge Van Den Wyngaert states in the Katanga case: "in order for a court of law to have the legal and moral authority to pass legal and moral judgment on someone, especially when it relates to such serious allegations as international crimes, it is essential (...) to scrupulously observe the fairness of the proceedings and to apply the standard of proof consistently and rigorously. It is not good enough that most of the trial has been fair. All of it must be fair." ${ }^{2}$ Here the reference to the court of law implies the role of the judges as the bearers of the authority reposed in the institution they speak in the name of, and from these fallible beings is expected a clear and shared understanding of fairness, as stipulated in the statutory responsibilities.

The acquittal by the Appeals Chamber in Prosecutor v. Jean Pierre Gombo $B e m b a^{53}$ and later the ICC's Pre Trial Chamber's decision regarding authorizing investigation of the situation in Afghanistan as being against the "interests of justice" 54 were questioned and challenged by those who believed the judges were not speaking in the name of the victims. Both cases demonstrated to scholars a failure of the judiciary to aid the prosecutor's case. ${ }^{55}$ What fairness was expected of these judges? Or were they recognized as mere cogs in a system that was ready to put another name on its list of sentenced criminals? What becomes unclear in this case is which of the two choices would increase the legitimacy of the court: one that puts more people away in prisons, or one that defers to the rule of law and processes even at the cost of acquittal? It becomes clear that the international community does not know the answer to that question. Therefore, to suppose that factors such as fairness of procedural guarantees is the way forward is to oversimplify the debate.

51 Rigney, S. (2015), “That a Trial is Fair”: The Centrality and Incoherence of Fairness in International Criminal Trials" In: A. Savarian et al. (eds), Procedural Fairness in International Courts and Tribunals. London: British Institute of International and Comparative Law, 119-134.

52 Prosecutor v. Katanga Judgment (Minority Opinion of Judge Christine Van Den Wyngaert), International Criminal Court, Trial Chamber II, Case No ICC-01/04-01/07, 7 March 2014, Judge Van Den Wyngaert, 311.

53 Case No ICC-01/05-01/08-3636-Red (Official Case No) ICL 1849 (ICC 2018).

54 ICC, Decision Pursuant to Article 15 of the Rome Statute on the Authorisation of an Investigation into the Situation in the Islamic Republic of Afghanistan, Pre-Trial Chamber II, 12 April 2019.

55 See: Sadat, supra note 36; Amman, supra note 36; Heinze, supra note 35. 


\section{Conclusion: The Road to Inequality is Paved with Democratic Intentions}

Whether the international courts offer the possibility of giving a voice to individuals who are affected by actions of a foreign state towards ameliorating problems of democratic inclusion, is a proposition that deserves further probing. Notwithstanding the absence of these individuals in the creation of the courts, can their representation be ensured by a procedural fairness that guarantees its legitimacy? As Aida Torres Pérez mentions in the previous chapter, should international courts (pretend to) speak in the name of anyone at all, other than the parties to the dispute?56 However, that falls short too, when we take into account the asymmetry of the parties. The individuals that the authors believe the international courts can shape the freedoms of often suffer from the very lack of freedom to access the court, or to participate in the transnational or global publics with which the authors claim they can engage critically. ${ }^{57}$ Not to suggest that international courts are entirely incompetent to provide for such rights and freedoms, but that they remain a distant recourse for many whose basic guarantees fail for reasons owing to the hierarchical structures, whether locally or globally. The discourse must first attend to the structural deficiencies of the system of international courts that exclude the groups who could best benefit from its power. The belief that the courts speak in the name of the people, even if indirectly, is more of an assuaging argument about an institutional mechanism that is here to stay, with all its shortcomings, and less a critical reflection that challenges our normative assumptions.

While I challenge the main hypotheses of courts and their democratic legitimacy, I admit that there are important victories won by various courts, especially the ECHR, that are able to limit the authoritarianism of States. Yet, it is necessary that we contest its contributions at every opportunity it appears deficient. For centuries, hegemons have created institutional frameworks that have appeared to work for the cause of the vulnerable, or the voiceless, against the authoritarianism of the existing systems, whilst in reality advancing their own causes and agendas. Several critical scholars like Anghie have exposed the underlying biases and interests that have continued to be at play in the guise of a humanitarianism. To ignore those biases in order to restore faith in the international system would at best be

56 Cf. the chapter written by Aida Torres Perez: "In Nobody's Name: A Checks and Balances Approach to International Judicial Independence”.

57 Von Bogdandy and Venzke, supra note 3, 212. 
a disservice to those who continue to rely on them for their piece of the pie. The competing interests along with the competing agendas of various courts and jurisdictions do not simplify the answer to the question "in whose name do the courts speak?". If anything, it exposes the complexity of the system of international adjudication, which remains a political project with very long genealogical roots. 